\title{
BITs, Colony Ties, and Offshore Centers: The Case of United Kingdom Outward FDI
}

\author{
Oleg Gurshev ${ }^{1+}$ and Sarhad Hamza ${ }^{1,2}$ \\ ${ }^{1}$ University of Warsaw, Poland \\ ${ }^{2}$ University of Raparin, Iraq
}

\begin{abstract}
This paper empirically investigates the impact of bilateral investment treaties (BITs) on foreign direct investment (FDI) using data on British multinational firms' outward FDI in a panel of 140 countries across 2009-2017. We apply the Knowledge-Capital model to demonstrate that BITs act as a market access mechanism to parent country multinational enterprises. Our core result confirms the negative impact of BIT membership on horizontal FDI in the host economy. This result is robust to changes in partner sample composition, hypothetical stock levels, and inclusion of trade policies. Our findings imply that factor cost advantages are unable to compensate for the adverse effect of BIT entry, which raises concerns regarding the potency of BIT-centered development policies.
\end{abstract}

Keywords: Foreign Direct Investment, Multinational Enterprises, United Kingdom, BITs, Poisson Pseudo-Maximum Likelihood

\section{Introduction}

Foreign direct investment (FDI) and multinational activities have been researched for over 40 years. This is because global FDI flows have increased from $\$ 49.8$ billion in 1987 to $\$ 1.39$ trillion in 2019 (UNCTAD, 2020a). The total annual inward FDI stock was nearly \$31.5 trillion, which almost triples the world's total volume of international trade (World Trade Organization, 2019). With the integration of international markets since the mid-1980s, world FDI flows have been growing stronger than trade and world gross domestic product (GDP), making inward and outward FDI stocks indicative factors over how well a country is integrated into the global economy. Hence, the bulk of developing and least-developed countries have shifted from internal industrialization strategies to FDI-supported economic development. This is because inward FDI

\footnotetext{
+Corresponding Author: Oleg Gurshev

Doctoral candidate, University of Warsaw, Faculty of Economic Sciences, Department of Macroeconomics and International Trade Theory, ul. Długa 44/50, 00-241 Warszawa, Poland. Email: o.gurshev@uw.edu.pl

Co-Author: Sarhad Hamza

Doctoral candidate, University of Warsaw, Faculty of Economic Sciences, Department of Macroeconomics and International Trade Theory, ul. Długa 44/50, Level 1, Room 04, 00-241 Warszawa, Poland. Email: sarhadhamza@uor.edu.krd
} 
may improve a host economy in several ways but mainly through technology transfer, employment, export promotion, accumulation of physical capital, and skill development (e.g., De Mello, 1997; Borensztein et al., 1998; Balasubramanyam et al., 1999; Bevan \& Estrin, 2004). Consequently, recipient countries set out policies that enhance the protection of foreign investors' property and contract rights, including promoting transparency of domestic markets (Drabek \& Payne, 2002). Therefore, the number of bilateral investment treaties (BITs) that were signed to facilitate market entry and subsequent investment of multinational enterprises (MNEs) has increased substantially to approximately 2,343 (UNCTAD, 2020b).1)

This study is not the first to examine the relationship between BITs and FDI.2) However, previous research has been broadly inconclusive because of the three key shortcomings: insufficient theoretical underpinnings for the empirical specification of the model, research design around the treaties, and potential partner selection bias.

To tackle these gaps, we apply the Knowledge-Capital (KK) model (Markusen, 2002) and have it accommodate the existence of colonial ties and BITs in the location decision of British MNEs. Our choice is motivated by the following stylized facts: First, the United Kingdom is currently a member of 117 BITs, of which 94 are currently in force, making the UK economy one of the most important BIT "parties" globally (UNCTAD, 2020b). Second, the United Kingdom remains among the most dynamic capital-exporting economies; in 2018, the outward FDI stock was estimated at $\$ 1.89$ trillion. Lastly, British MNEs exhibit a diversified sectoral distribution among their partner countries, as the bulk of FDI stock is concentrated in sectors such as financial services ( $\$ 497.21$ billion), mining and quarrying ( $\$ 143.79$ billion), chemicals and petroleum products ( $\$ 136.47$ billion), information and communication ( $\$ 161.00$ billion), retail and wholesale trade ( $\$ 112.61$ billion), and foodstuffs and beverages ( $\$ 99.77$ billion) (Office for National Statistics, 2020).

However, recent empirical evidence indicates that not all outward FDI may be considered "real" financial investment. For example, in less than a decade, phantom FDI has climbed from approximately $30 \%$ to almost $40 \%$ of global FDI. This case becomes significantly greater when considering offshore centers such as Luxembourg, the Netherlands, Hong Kong SAR, and Singapore, which generate phantom or pass-through FDI because of corporate tax evasion (Damgaard et al., 2019). Consequently, this raises concerns over the sensitivity of empirical results when using the national FDI data. Particularly, we argue, that phantom FDI may distort

1) BITs are legal instruments of enforcement of property rights signed between large capital exporting economies to encourage investments relationship (Lee \& Johnston, 2016), which leads to better economic prospects for foreign investors (Gallagher \& Birch, 2006). BITs stipulate the terms and conditions by which investors from one state must be treated by the other (Jacobs, 2017).

2) See for example, UNCTAD (1998), Halward-Dreimer (2003), Salacuse and Sullivan (2005), Egger and Pfaffermayr (2004), Tobin and Ackerman (2005), Neumayer and Spess (2005), Galagher and Birch (2006), and Busse and Nunnenkamp (2010). A brief summary and discussion of these papers are in Section 2. 
empirical results by overestimating or underestimating the role of factor endowments in determining drivers behind FDI in host economies.

The main goal of this paper is threefold: First, we investigate the economic impact of BITs and colonial links using the theoretical framework of the KK model (Markusen, 2002) on a panel of 140 investment partners across 2009-2017 to pinpoint the exact motives of British outward FDI in the partner countries. Second, we study a counterexample to our general case results while intentionally excluding possible phantom FDI partners and Western offshoot colonies. Lastly, we conduct a sensitivity analysis that considers hypothetical FDI stock levels derived from Damgaard et al. (2019) in our phantom partner sample to illustrate the sensitivity of our empirical analysis.

Our contribution can be summarized as follows: first, this study is the first to extend the mainstream multinational production theory to empirically examine the economic effects of BITs on FDI. By using data on British firms, we can examine the joint effects of colonial ties and BITs. Furthermore, we are the first to examine a possible phantom partner bias in our sample of FDI partners in connection to BITs. Finally, unlike previous literature on dyadic studies of BIT effects on FDI, we do not account for the total number of BITs signed by a host country; instead, our study assumes that the treaties act as a market access mechanism for parent country MNEs.3) Such approach is novel and generates tractable results.

The remainder of this paper proceeds as follows. Section 2 provides the literature review, Section 3 describes our analytical framework and formulates research hypotheses, Section 4 discusses the properties of our dataset and empirical methodology, Section 5 reports and discusses empirical analysis, and Section 6 presents the conclusion.

\section{Literature Review}

Early studies on the determinants of multinational activity primarily focused on explaining two-way FDI flows between advanced economies. The first theoretical models of horizontal FDI were proposed by Krugman (1983) and Markusen (1984)4), whereas Helpman (1984) and Helpman and Krugman (1985) introduced the first models of vertical FDI to explain FDI arising between developed and developing countries due to the observed differences between physical capital endowments per worker. Consequently, the next generation of models merged horizontal and vertical motives for FDI (Markusen, 2002; Bergstrand \& Egger, 2007; 2013).5) Particularly,

3) Dyadic data structure makes use of bilateral interaction between parent and host countries, whereas monadic data structure utilizes aggregate levels of both "active" BITs and received volume of FDI.

4) Their seminal models have been extended by, inter alia, Horstmann and Markusen (1987), Markusen and Venables (1998, 2000), Helpman et al. (2004), Cieślik (2013, 2016, 2018), and Cieślik and Ryan (2012). 
Markusen (2002) proposed the unified framework of the KK model of MNE in which firms can choose between exporting horizontal and vertical types of FDI.

The original empirical application of the KK model was to explain relative factor endowments affecting aggregate multinational activity using a panel on bilateral country-level affiliate sales of US-based multinationals. The main findings include convergence in income levels between investment partners as the horizontal motive of inward FDI and similarity in the endowment of production factors as the vertical motive (Carr et al., 2004). The empirical work was further advanced by Gao (2003), who included an additional variable to account for ethnic networks in China. Waldkirch (2010), who studied German MNEs, indicated that FDI is more likely to occur between similarly endowed countries. Arnold and Javorcik (2009), Guadalupe et al. (2012), and Blonigen and Piger (2014) have focused on the market entry modes of MNEs and suggested that the most productive firms tend to be the targets of foreign acquisitions.

As mentioned earlier, the existing literature studying the relationship between BITs and FDI has found contradictory results. For example, UNCTAD (1998) studied the impact of BITs on inward FDI flows from 14 developed capital-exporting countries into 72 capital-importing developing countries throughout 1971-1994 and found no relationship between BITs and FDI inflows. Hallward-Driemeier (2003) used the data on bilateral FDI flows from 20 OECD members into 31 developing countries between 1980 and 2000 and raises further doubts regarding the effect of BITs on FDI. Tobin and Ackerman (2005) obtained similar findings when studying the effect of BITs on 5 year averages of aggregate FDI inflows into 63 developing countries from 1985 to 2000, concluding that "BITs do not encourage FDI except at low levels of political risk" (p. 22). Busse and Nunnenkamp (2010) used unilateral FDI flows and applied the gravity model with various model specifications, including an instrumental variable approach. When excluding the transition countries of central and eastern Europe, they find a small effect of BITs on FDI flows to developing countries.

However, other empirical studies have argued that BITs have a positive impact on FDI (Egger \& Pfaffermayr, 2004; Neumayer \& Spess, 2005; Salacuse \& Sullivan 2005; Haftel, 2008; Kerner, 2009). In particular, Egger and Pfaffermayr (2004) applied the KK model to evaluate the impact of BITs between OECD and developing countries and ascertain the positive and significant effect of BITs on FDI. Neumayer and Spess (2005) utilized large panel data across 1970-2001 to examine the relationship of BITs on developing countries. On the basis of random and fixed-effects models, they presented empirical evidence that BITs increase inward FDI. Salacuse and Sullivan (2005) analyzed limited dyad pairs comprising the United States

5) In the horizontal type of FDI, firms face the trade-off between maximizing proximity to households and concentrating production to achieve economies of scale. By contrast, vertical type of FDI is related to countries' differences in relative factor endowments. Hence, firms engaging in horizontal FDI would be driven by the size and growth of the host country, whereas vertical FDI seeks cost competitiveness and other factors such as quality of domestic institutions, political risks, and physical infrastructure. 
and developing countries to find positive and highly significant relationships between BIT within the United States and FDI flows to the host economy. However, performing a similar study over 24 Latin American countries and the United States, Gallagher and Birch (2006) found no statistical significance of BITs on inward FDI. Haftel (2008) replicated Salacuse and Sullivan's (2005) research but only included signed and ratified BITs to achieve results consistent with the original findings.

Although these studies have attempted to shed light on BITs and FDI, the results have been largely conflicting because of various issues such as insufficient theoretical underpinnings for the empirical specification of regressions, partner sample composition, phantom FDI, and "omitted variable bias specifically in monadic and cross-sectional analyses" (Sauvant \& Sachs, 2009).

By contrast, we apply a large dyadic panel that features 140 partners across 2009-2017 and use more accurate measurements of FDI. Moreover, our methodological approach to the BIT mechanism differs from the existing literature because we argue that BITs essentially provide a market entry point to MNEs. To ensure robustness, we apply advanced econometric tools and address recent findings regarding the role of phantom FDI. Finally, we derive our hypotheses directly from the KK model, which is regarded as the most general model of MNE currently available (Davis and Markusen, 2020). Ultimately, we scrutinize whether treaties promote inward FDI and deliver new results that advance the prior literature.

\section{Analytical Framework and Hypotheses Development}

Markusen's (2002) original KK model was based on three principal assumptions. First, services of knowledge-based activities such as R\&D, patents, and know-how can be geographically separated from physical production and supplied to operating facilities at low cost. Second, the knowledge-based activities are skilled labor intensive relative to production. The first two assumptions imply the vertical fragmentation of MNE operations, where skilled-intensive facilities are located in advanced human capital abundant economies, whereas actual production takes place elsewhere. Finally, the knowledge-based services have a partial joint-input characteristic, allowing for simultaneous usage by multiple production facilities. This creates firm-level economies of scale and motivates the horizontal investments that serve domestic markets with principally similar goods to those available in the parent country. Hence, the resulting trade interaction between countries in the model is endogenous.

The model assumes two homogeneous goods ( $X$ and $Y$ ), two countries $(H, F)$, and two homogeneous factors, unskilled labor $(L)$ and skilled labor $(S) . L$ and $S$ are internationally immobile. Good $Y$ is unskilled labor-intensive, produced under constant returns to scale in a perfectly competitive industry, whereas good $X$ is skilled labor-intensive, produced at 
increasing returns to scale at the plant level, and is subject to oligopolistic competition $\grave{a}$ la Cournot with free market entry and exit. Such market structure allows several types of firms to rise in equilibrium. The equilibrium can feature national firms (N-type firms) that serve domestic market and export abroad, horizontally integrated firms (H-MNEs) with two plants in both $H$ and $F$ countries with no trade, and vertically integrated firms (V-MNEs) that maintain headquarters and plant in different countries with exports from an affiliate to a parent.

The cross-country distribution of these three types of firms in the equilibrium is driven by country-pair endowment characteristics. For example, N-type firms arise if one of the countries is relatively larger and trade costs are low, which encourages domestic production and exports to a smaller country. H-MNEs become important once both $H$ and $F$ are similar in size and factor endowments, whereas trade costs are high as firms will find it advantageous to locate in a different country and serve domestic markets to avoid transportation and trade costs. However, if countries have different factor endowments and trade costs are low, firms prefer specializing vertically and leveraging the variation in skilled and unskilled labor between $H$ and $F$. Finally, the model allows all three types of firms to coexist in equilibrium. Thus, we argue that it is feasible to adopt the KK model for our empirical study. The model allows us to differentiate between pure horizontal and vertical reasons for FDI as the expected impacts of particular country characteristics may differ between the motives of investment. For example, joint market size and access will be associated with a horizontal motive, whereas market size difference and human capital endowment are vertical motives.

We extend "market barriers" to include investment treaties and colony ties. We hypothesize that the former serves as a market entry point, which departs from the conventional treatment of BITs, where they simply reduce the costs of investing abroad or signal to a potential investor whose hosts are serious about the protection of property and contract rights (Egger \& Pfaffermayr, 2004; Neumayer \& Spess, 2005). By contrast, the latter resembles the accumulated experience of British MNEs in doing business in that particular host economy.

In summary, we use differences in human capital endowments, output characteristics, bilateral trade and investment barriers, and distance between countries as a base and propose these hypotheses:

$H_{1}$ : BITs decrease horizontal type of FDI because of the improved market access to MNEs in the host economy.

$H_{2}$ : Colonial ties between the United Kingdom and host country increase horizontal and vertical types of FDI.

$H_{3}$ : The presence of phantom partners' and Western offshoot colonies' stock in the pooled estimation leads to an overestimation of the vertical motive of FDI alongside the positive effect on the joint colony-BIT relationship. 


\section{Data and Methodology}

Our dependent variable (outward FDI stock) is measured using the data on FDI position abroad collected from annual report of Office for National Statistics (2020). We use equity stocks owned by British MNEs in partner countries; Figure A1 (Appendix) illustrates the average annual outward FDI stock of British MNEs between 2009 and 2017. Instead of net flow data, which are often subject to frequent fluctuations, the influence of debt instruments, and higher distortion due to phantom FDI, stock data were used because they represent "the long-run factors that explain the distribution of FDI" (Blonigen \& Piger, 2014, p.782). The explanatory variables cover 2008-2017 to account for the lagged estimation. Despite FDI stock data being available for more recent years, the last year of our sample is 2017 because of the data availability for our explanatory variables, which are obtained from the Penn World Table 9.1 (Feenstra et al., 2015). The final data set covers 140 partner countries between 2008 and 2017 and yields 1,260 observations. The complete list of investment partners is in Table A1 (Appendix).

The difference in the market size between parent and host countries is measured using the squared difference in output-side real GDPs (GDP_DIFF). To assure international comparability each country's GDP is measured at chained PPPs and expressed in constant 2011 US dollars. The value of this index is positively related to the similarity in economic size of both investment partners and is maximized when both the home and host countries are of relatively equal size. The GDP data are sourced from the PWT.

The difference in factor proportions between the parent and host countries is measured using the per worker difference in human capital (HC_DIFF), which is calculated using the human capital index, measured in schooling years and returns to education. The factor proportion data are sourced from the PWT.

Distance related trade costs between the parent and host countries are expressed as a geographic distance (DISTANCE), measured in kilometers as the distance between the parent country's capital city (London) and the host country's capital. The data are obtained from the Center d'Etudes Prospectives et d'Informations Internationales gravity database (CEPII).

We control for colonial ties between the parent and host countries using a dummy variable, which takes the value of 1 if a host country was part of the British Empire and 0 otherwise. We acknowledge a possible limitation of using a single dummy for the colonial relationship between the parent and host countries. However, because of the complex nature of such relationship, we do not pursue to analyze it further and focus on the interplay between colony and BIT variables. The colonial dummy is obtained from the CEPII.

Unlike the previous literature on dyadic studies of BITs, we do not account for the total number of BITs signed by a host country; instead, our study assumes that the treaties are homogeneous and act as a market access mechanism for parent country MNEs. $\left.{ }^{6}\right)$ The approach 
is novel and generates tractable results. Thus, we use a dummy variable to approximate the existence of a treaty between the parent and host countries. Our BIT dummy takes the value of 1 if the host country had/still has an in force BIT with the United Kingdom and 0 otherwise. The data for the BIT dummy are sourced from the UNCTAD Investment Policy Hub (2020) and World Bank's International Center for Settlement of Investment Disputes (ICSID) database (2020). Our sample covers 71 countries, an overwhelming economic majority of the United Kingdom's active BIT partners.

To approximate trade and investment barriers, red taping, and bureaucracy, we include trade and investment freedom indexes for the parent and host countries: $\mathrm{TF}_{\mathrm{PARENT}}, \mathrm{TC}_{\mathrm{HOST}}$, and $\mathrm{IC}_{\mathrm{HOST}}$. The trade freedom index indicates the level of protective tariffs and nontariff barriers in a given country. The investment freedom index measures freedom from restrictions on the movement and use of investment capital within and across the country's borders. The higher values of these indexes are associated with more open and liberal trade and investment regimes and vice versa. Both indexes are sourced from the Heritage Foundation (2020) Index of economic freedom database.

Finally, we control for the combined economic size of investment partners, measured as the sum of the parent and host countries' GDP (GDP_SUM). The joint economic size variable is calculated using the real GDP data expressed at constant 2011 national prices in US dollars, with the data being sourced from the PWT.

The detailed definitions of our explanatory variables and their summary statistics are reported in Tables A2 and A3 (Appendix), whereas their pairwise correlations are presented in Table A4 (Appendix).

The estimation for our empirical analysis can be formally stated as follows:

$$
\begin{aligned}
F D I_{i j t}= & \beta_{0}+\beta_{1} \ln \left[\left(Y-Y_{j t}\right)^{2}\right]+\beta_{2} \ln \left[\left|\frac{H_{i t}}{L_{i t}}-\frac{H_{j t}}{L_{j t}}\right|\right]+\beta_{3} \ln \left[\left(Y_{i t}+Y_{j t}\right)\right] \\
& +\beta_{4} \ln \left[D I S T A N C E_{i j}\right]+\beta_{5} T F_{i t}+\beta_{6} T C_{j t}+\beta_{7} I C_{j t}+\beta_{8} B I T_{i j t} \\
& +\beta_{9} C O L O N Y_{i j}+\beta_{10}\left[B I T_{i j t} * C O L O N Y_{i j}\right]+\epsilon_{i j t},
\end{aligned}
$$

where $F D I_{i j t}$ is bilateral outward FDI stock from source country $i$ to host country $j$ in year $t_{i t} ; Y_{i t}$ and $Y_{j t}$ are GDPs of country $i$ and country $j$ in year $t ; \frac{H_{i t}}{L_{i t}}$ and $\frac{H_{j t}}{L_{j t}}$ are human capital per worker endowments for country $i$ and country $j$ in year $t$; DISTANCE $E_{i j}$ is the distance between the capitals of country $i$ and country $j$; BIT $T_{i j t}$ is dummy variable, reflecting country $i$ and country $j$ membership in the BIT in year $t$; COLONY $Y_{i j}$ is dummy variable, reflecting

6) See Salacuse and Sullivan (2005), Gallagher and Birch (2006), and Haftel (2008). 
the colonial relationship between country $i$ and country $j$, whereas $T F_{i t}, T C_{j t}$, and $I C_{j t}$ are trade and investment freedom indexes for country $j$ and country $i$ in year $t ;\left[B I T_{i j t}{ }^{*} C O L O N Y_{i j}\right]$ is an interaction term for two dummies, which approximates the effect of country $i$ membership in the BIT in year $t$ and having the colonial relationship with country $j$; and $\epsilon_{i j t}$ is the error term, for $i=$ the United Kingdom, $j=1, \ldots, 140$ investment partners, $t=2008, \ldots, 2017$, and $\beta$ s are the parameters to be estimated.

To empirically estimate specification (1), we apply the Poisson pseudo-maximum likelihood (PPML) estimator because it has several desired properties. First, it assists in mitigating Jensen's inequality, which is the following:

$$
E[g(X)] \neq \ln [E(y)]
$$

One of the implications of Jensen's inequality is that the standard practice of interpreting the parameters of log-linearized models estimated by ordinary least squares (OLS), especially in cases where the dependent variable is log-transformed, can be highly misleading (Silva and Tenreyro, 2006). Second, the estimator naturally includes observations, for which the observed value is 0 ; hence, the original FDI data do not need additional manipulations, such as the use of absolute amounts, truncation, or negative-to-positive transformations found in BIT literature (Jacobs, 2017). This is because the estimator permits the existence of zero in its first-order conditions:

$$
\sum_{i=1}^{n}\left[y_{i}-\exp \left(x_{i} \tilde{\beta}\right)\right] x_{i}=0
$$

Third, the given data do not need to follow Poisson distribution; instead, the estimator assumes that the conditional variance is proportional to the conditional mean or $E\left[y_{i} \mid x\right]=\exp \left(x_{i} \beta\right) \propto V\left[y_{i} \mid x\right]$, and gives the same weight to all observations in the data set. This is appealing because a significant number of BIT partners in our sample do not observe any inward FDI from British MNEs. Finally, the estimator is consistent with fixed-effects, and the interpretation of the parameters follows the same pattern as under OLS. When compared with other approaches such as OLS, nonlinear least squares, feasible generalized least squares, and ET-Tobit models, the PPML can produce the most consistent unbiased estimates, even when the proportion of zeros in the sample is very large (Silva \& Tenreyro, 2011). 


\section{Empirical Analysis}

Our empirical analysis has three parts: (1) investigating a general case with all partners present in the estimation, (2) investigating a more restrictive case where we intentionally exclude potential phantom FDI partners together with the Western offshoot colonies, and (3) checking the sensitivity of our results from the restrictive case on the basis of different assumptions regarding the relative proportion of real FDI stocks located in phantom partners.

The baseline estimation results for our general case obtained from specification (1) without controlling for individual time effects are reported in column (1) of Table 1. All of the estimated coefficients are statistically significant and display the signs that are in line with the KK model. The reported coefficients favor the horizontal reason for FDI, although the vertical motive remains present even though variables commonly associated with it such as GDP_DIFF and HC_DIFF display low magnitude and statistical significance compared to GDP_SUM, TC $\mathrm{HOST}_{\text {, }}$ $\mathrm{IC}_{\mathrm{HOST}}$, and $\mathrm{TF}_{\text {PARENT }}$. Furthermore, the estimated parameter on our BIT dummy is negative and significant at the $1 \%$ level, confirming our hypothesis that treaties act as a market access mechanism and therefore play a counter role by increasing horizontal types of FDI. Additionally, the estimated parameters on COLONY and $\mathrm{BIT}{ }^{*} \mathrm{COL}$ interaction term are positive and significant at the $1 \%$ level, indicating that countries with either only colonial ties or signed treaties tend to experience an increase in inward FDI stock. However, in our approach, it is not entirely permissible to disaggregate the exact investment motive behind these two variables. Despite this, we hypothesize that these two parameters are driven by the FDI stocks located in the Western offshoot colonies such as Australia, Canada, and the United States and phantom partners such as Hong Kong SAR, Luxembourg, the Netherlands, and Panama.

The robustness of our general case results is examined in the subsequent columns of Table 1. Column (2) reports estimation results obtained from specification (1), having controlled for individual time effects. The results are almost identical in qualitative terms compared with those in column (1) and support the horizontal motive of FDI in the pooled sample of partners. In the case of time effects, the estimated parameters on the $\mathrm{TF}_{\text {PARENT }}$ variable display the expected sign but lose their statistical significance.

Column (3) reports estimation results obtained from specification (1) with one-period lagged independent variables to avoid the potential simultaneity problem. The reported estimation results are similar in qualitative terms in column (2). In this case, the estimated parameters point to a stronger horizontal motive of FDI as the parameter on the HC_DIFF variable is no longer statistically significant at the $10 \%$ level. Also, we observe an erosion of statistical significance in the BIT*COL interaction term compared with those in columns (1) and (2).

Column (4) reports estimation results obtained from specification (1) with one-period lagged independent variables, having controlled for individual time effects. The results are very similar 
in qualitative terms compared with those in column (3) and further confirm the horizontal motive of FDI in the pooled sample of partners. Overall, the reported general case results in Table 1 are consistent with $H_{1}$ and $H_{2}$.

Table 1. Estimation Results, General Case

\begin{tabular}{|c|c|c|c|c|}
\hline Exp. var. & (1) & (2) & (3) & (4) \\
\hline \multirow[t]{2}{*}{ GDP_DIFF } & $-0.153^{* *}$ & $-0.152^{* *}$ & $-0.158^{* * *}$ & $-0.159^{* * *}$ \\
\hline & $(0.0473)$ & $(0.0478)$ & $(0.0442)$ & $(0.0440)$ \\
\hline \multirow[t]{2}{*}{ HC_DIFF } & $0.180^{*}$ & $0.180^{*}$ & 0.156 & 0.157 \\
\hline & $(0.0796)$ & $(0.0797)$ & $(0.0819)$ & $(0.0811)$ \\
\hline \multirow[t]{2}{*}{ GDP_SUM } & $2.235^{* * *}$ & $2.240^{* * *}$ & $2.145^{* * *}$ & $2.150^{* * *}$ \\
\hline & $(0.195)$ & $(0.196)$ & $(0.195)$ & $(0.197)$ \\
\hline \multirow[t]{2}{*}{ DISTANCE } & $-0.553^{* * *}$ & $-0.553^{* * *}$ & $-0.532^{* * *}$ & $-0.531^{* * *}$ \\
\hline & $(0.0770)$ & $(0.0774)$ & $(0.0738)$ & $(0.0739)$ \\
\hline \multirow[t]{2}{*}{$\mathrm{TC}_{\text {HOST }}$} & $0.0518^{* * *}$ & $0.0527^{* * *}$ & $0.0568^{* * *}$ & $0.0602^{* * *}$ \\
\hline & $(0.0116)$ & $(0.0112)$ & $(0.0123)$ & $(0.0119)$ \\
\hline \multirow[t]{2}{*}{$\mathrm{IC}_{\text {HOST }}$} & $0.0457^{* * *}$ & $0.0458^{* * *}$ & $0.0471^{* * *}$ & $0.0468^{* * *}$ \\
\hline & $(0.00707)$ & $(0.00714)$ & $(0.00689)$ & $(0.00689)$ \\
\hline \multirow[t]{2}{*}{$\mathrm{TF}_{\text {PARENT }}$} & $0.0793^{*}$ & 0.0797 & 0.0520 & 0.0631 \\
\hline & $(0.0312)$ & $(0.0543)$ & $(0.0306)$ & $(0.0537)$ \\
\hline \multirow[t]{2}{*}{ BIT } & $-1.690^{* * *}$ & $-1.682^{* * *}$ & $-1.238^{* * *}$ & $-1.227^{* * *}$ \\
\hline & $(0.172)$ & $(0.171)$ & $(0.172)$ & (0.169) \\
\hline \multirow[t]{2}{*}{ COLONY } & $0.488^{* * *}$ & $0.483^{* * *}$ & $0.621^{* * *}$ & $0.601^{* * *}$ \\
\hline & $(0.142)$ & $(0.142)$ & $(0.156)$ & $(0.156)$ \\
\hline \multirow[t]{2}{*}{$\mathrm{BIT} * \mathrm{COL}$} & $1.409^{* * *}$ & $1.413^{* * *}$ & $0.714^{*}$ & $0.732^{*}$ \\
\hline & $(0.290)$ & $(0.290)$ & $(0.299)$ & $(0.297)$ \\
\hline \multirow[t]{2}{*}{ cons } & $-36.54^{* * *}$ & $-36.78^{* * *}$ & $-33.58^{* * *}$ & $-34.91^{* * *}$ \\
\hline & (3.331) & $(5.066)$ & (3.246) & (5.119) \\
\hline Time effects & No & Yes & No & Yes \\
\hline$N$ & 1260 & 1260 & 1260 & 1260 \\
\hline
\end{tabular}

Note: Robust standard errors in parentheses; ${ }^{* * *} p<0.01$, ** $p<0.05, * p<0.1$ (Source) Own calculation.

We now investigate a case where we intentionally exclude the phantom FDI partners together with the Western offshoot colonies and rerun specification (1) to report the sensitivity of our general case results. The baseline results are reported in column (1) of Table 2. The two notable changes are as follows: The estimated coefficient on the HC_DIFF variable is no longer statistically significant, and the sign of the $\mathrm{BIT} * \mathrm{COL}$ interaction term is reversed and significant at the $1 \%$ level. Such results partially confirm our hypothesis that outside of the phantom partners 
and Western offshoot colonies, developing and least-developed partners that have both signed treaties with the United Kingdom and colonial ties tend to experience a significant decrease in FDI stocks. Second, in our panel, the significance of HC_DIFF is also associated with the phantom partners that experience disproportionally large inward FDI stocks from the British MNEs. Such results imply that developing and least-developed countries are not able to fully compensate for the loss in horizontal FDI stocks by attracting vertical ones. Finally, the remaining coefficients remain to be statistically significant and display the signs that are in line with the theory and favor the horizontal reason for FDI over the vertical one.

Table 2. Estimation Results, Excluding Offshores and Western "Offshoots"

\begin{tabular}{|c|c|c|c|c|}
\hline Exp. var. & (1) & (2) & (3) & (4) \\
\hline \multirow[t]{2}{*}{ GDP_DIFF } & $-0.161^{* * *}$ & $-0.161^{* * *}$ & $-0.0918^{* *}$ & $-0.0919^{* *}$ \\
\hline & $(0.0331)$ & $(0.0337)$ & $(0.0335)$ & $(0.0332)$ \\
\hline \multirow[t]{2}{*}{ HC_DIFF } & 0.120 & 0.122 & 0.00757 & 0.00931 \\
\hline & $(0.0624)$ & $(0.0629)$ & $(0.0665)$ & $(0.0660)$ \\
\hline \multirow[t]{2}{*}{ GDP_SUM } & $2.133^{* * *}$ & $2.139^{* * *}$ & $2.237^{* * *}$ & $2.246^{* * *}$ \\
\hline & $(0.208)$ & $(0.205)$ & $(0.158)$ & $(0.157)$ \\
\hline \multirow[t]{2}{*}{ DISTANCE } & $-0.831^{* * *}$ & $-0.832^{* * *}$ & $-0.744^{* * *}$ & $-0.749^{* * *}$ \\
\hline & $(0.0778)$ & $(0.0780)$ & $(0.0790)$ & $(0.0780)$ \\
\hline \multirow[t]{2}{*}{$\mathrm{TC}_{\text {HOST }}$} & $0.0285^{* *}$ & $0.0298^{* *}$ & $0.0526^{* * *}$ & $0.0557^{* * *}$ \\
\hline & $(0.0109)$ & $(0.0111)$ & $(0.0115)$ & $(0.0118)$ \\
\hline \multirow[t]{2}{*}{$\mathrm{IC}_{\text {HOST }}$} & $0.0210^{* * *}$ & $0.0205^{* * *}$ & $0.0111^{*}$ & $0.0100^{*}$ \\
\hline & $(0.00599)$ & $(0.00602)$ & $(0.00451)$ & $(0.00436)$ \\
\hline \multirow[t]{2}{*}{$\mathrm{TF}_{\text {PARENT }}$} & $0.101^{* *}$ & 0.178 & 0.0249 & 0.194 \\
\hline & $(0.0342)$ & $(0.423)$ & $(0.0225)$ & $(0.500)$ \\
\hline \multirow[t]{2}{*}{ BIT } & $-0.808^{* * *}$ & $-0.806^{* * *}$ & $-0.980^{* * *}$ & $-0.965^{* * *}$ \\
\hline & $(0.148)$ & $(0.148)$ & $(0.146)$ & $(0.146)$ \\
\hline \multirow[t]{2}{*}{ COLONY } & $0.496^{* *}$ & $0.499^{* *}$ & $0.965^{* * *}$ & $0.954^{* * *}$ \\
\hline & $(0.174)$ & $(0.174)$ & $(0.148)$ & $(0.147)$ \\
\hline \multirow[t]{2}{*}{$\mathrm{BIT} * \mathrm{COL}$} & $-1.853^{* * *}$ & $-1.853^{* * *}$ & $-2.440^{* * *}$ & $-2.407^{* * *}$ \\
\hline & $(0.335)$ & $(0.335)$ & $(0.368)$ & $(0.363)$ \\
\hline \multirow[t]{2}{*}{ _cons } & $-31.51^{* * *}$ & -37.99 & $-31.32^{* * *}$ & -45.83 \\
\hline & (3.967) & $(35.24)$ & $(2.293)$ & (41.74) \\
\hline Time effects & No & Yes & No & Yes \\
\hline$N$ & 1125 & 1125 & 1125 & 1125 \\
\hline
\end{tabular}

Note: Robust standard errors in parentheses; *** $p<0.01$, ** $p<0.05$, * $p<0.1$

(Source) Own calculation.

The robustness of the results obtained from the restricted case is reported in the subsequent 
columns of Table 2. Column (2) reports estimation results obtained from specification (1), having controlled for individual time effects. The results are almost identical in qualitative terms compared to column (1) and support the horizontal motive of FDI in the reduced sample of partners. In the case of time effects, the estimated parameters on the $\mathrm{TF}_{\mathrm{PARENT}}$ variable display the expected sign but lose their statistical significance compared to column (1).

Column (3) reports estimation results obtained from specification (1) with one-period lagged independent variables. The reported estimation results are similar in qualitative terms in column (1). In this case, the estimated parameters point to a stronger horizontal motive of FDI as the parameter on HC_DIFF becomes marginally small, and the estimated coefficient on $\mathrm{IC}_{\mathrm{HOST}}$ variable downgrades its significance level, while the interaction term BIT*COL increases its magnitude compared to columns (1) and (2).

Finally, column (4) reports estimation results obtained from specification (1) with one-period lagged independent variables, having controlled for individual time effects. The results are very similar in qualitative terms compared to column (3) and further confirm the horizontal motive of FDI in the reduced sample of partners. The reported restricted case results in Table 1 are consistent with $\mathrm{H}_{3}$.

Although, the findings presented in Tables 1 and 2 indicate strong statistical evidence on the impact of BIT membership on horizontal FDI. Our methodology potentially has an obvious missing point because the free market entry of MNEs is possible through other conditions, such as various trade promotion policies (e.g., downward bias in the estimation strategy). Thus, in Part B (Appendix), we provide additional estimation results using data on the bilateral preferential trade agreements between the UK and our partner sample under the Generalized System of Preferences.

We now investigate the threshold between our general and restricted cases. Damgaard et al. (2019) decompose inward FDI position into real FDI and phantom FDI using data on Special Purpose Entities (SPEs) and non-SPEs.7) They estimate, that for financial centers such as Luxembourg, the Netherlands, Hong Kong SAR, and Panama real FDI can be as low as 5\% of the total FDI stock. Hence, they proceed to apply such a share of real FDI stock uniformly across all counterpart economies. Thus, we proceed to apply this methodology to our phantom partners, though we study possible levels of this assumption by gradually increasing the share of real FDI in phantom partners. Table 3 reports our findings for the complete sample of partners, excluding Western offshoot colonies. ${ }^{8)}$ Table 3 reports our results for specification (1), having controlled for individual time effects in the new setting. Columns (1)-(5) report estimates for

7) Firms that are used in offshore centers to take advantage of differences in regulatory environments between parent and host countries.

8) Australia, Canada, New Zealand, and others are intentionally excluded as they share robust Real FDI links with the UK. 
the different levels of real FDI in phantom partners. Particularly, column (1) reports results obtained using the original decomposition of Damgaard et al. (2019), the results are very similar in quantitative terms to the ones from Table 2, while columns (2)-(5) report a gradual increase in the levels of real FDI stock in phantom partners, the estimated parameters on our variables begin to shift to the general case results of Table 2. These results are quite intuitive, as we increase the share of real FDI stock in phantom partners, the estimated parameters shift from the restricted case results in Table 2 to the general case results in Table 1. Most notably, the increase of real FDI stock leads to an overestimation of the vertical motive of FDI and has a positive effect on the joint COL*BIT interaction term. The threshold is located somewhere

Table 3. Sensitivity of the Special Case Results to the Relative Proportion of Outward FDI Stocks Located in Phantom Partners, Excluding Western "Offshoots"

\begin{tabular}{|c|c|c|c|c|c|}
\hline Exp. var. & $\begin{array}{l}5 \% \\
\text { (1) }\end{array}$ & $\begin{array}{c}10 \% \\
(2)\end{array}$ & $\begin{array}{c}15 \% \\
(3)\end{array}$ & $\begin{array}{c}20 \% \\
(4)\end{array}$ & $\begin{array}{c}25 \% \\
(5)\end{array}$ \\
\hline \multirow[t]{2}{*}{ GDP_DIFF } & $-0.145^{* * *}$ & $-0.153^{* * *}$ & $-0.152^{* * *}$ & $-0.164^{* * *}$ & $-0.170^{* * *}$ \\
\hline & $(0.30)$ & $(0.0295)$ & $(0.029)$ & $(0.029)$ & $(0.0296)$ \\
\hline \multirow[t]{2}{*}{ HC_DIFF } & 0.0567 & 0.0784 & 0.078 & $0.112^{* *}$ & $0.126^{* *}$ \\
\hline & $(0.053)$ & $(0.0514)$ & $(0.051)$ & $(0.050)$ & $(0.0501)$ \\
\hline \multirow[t]{2}{*}{ GDP_SUM } & $2.165^{* * *}$ & $2.124^{* * *}$ & $2.124^{* * *}$ & $2.048^{* * *}$ & $2.013^{* * *}$ \\
\hline & $(0.187)$ & $(0.189)$ & $(0.188)$ & $(0.197)$ & $(0.204)$ \\
\hline \multirow[t]{2}{*}{ DISTANCE } & $-0.746^{* * *}$ & $-0.755^{* * *}$ & $-0.754^{* * *}$ & $-0.770^{* * *}$ & $-0.777^{* * *}$ \\
\hline & $(0.0780)$ & $(0.0761)$ & $(0.076)$ & $(0.074)$ & $(0.0748)$ \\
\hline \multirow[t]{2}{*}{$\mathrm{TC}_{\text {HOST }}$} & $0.0438^{* * *}$ & $0.0401^{* * *}$ & $0.040^{* * *}$ & $0.033^{* * *}$ & $0.0303^{* *}$ \\
\hline & $(0.0118)$ & $(0.0113)$ & $(0.011)$ & $(0.010)$ & $(0.0110)$ \\
\hline \multirow[t]{2}{*}{$\mathrm{IC}_{\text {HOST }}$} & $0.0147^{* * *}$ & $0.0182^{* * *}$ & $0.018^{* * *}$ & $0.024^{* * *}$ & $0.0276^{* * *}$ \\
\hline & (0.00539) & $(0.00543)$ & $(0.005)$ & $(0.005)$ & $(0.00586)$ \\
\hline \multirow[t]{2}{*}{$\mathrm{TF}_{\text {PARENT }}$} & 0.160 & 0.156 & 0.156 & 0.148 & 0.145 \\
\hline & $(0.410)$ & $(0.390)$ & $(0.389)$ & $(0.363)$ & $(0.356)$ \\
\hline \multirow[t]{2}{*}{ BIT } & $-0.902^{* * *}$ & $-0.925^{* * *}$ & $-0.925^{* * *}$ & $-0.970^{* * *}$ & $-0.992^{* * *}$ \\
\hline & $(0.144)$ & $(0.143)$ & $(0.142)$ & $(0.140)$ & $(0.141)$ \\
\hline \multirow[t]{2}{*}{ COLONY } & $0.685^{* * *}$ & $0.572^{* *}$ & $0.571^{* * *}$ & $0.374^{* *}$ & $0.288^{*}$ \\
\hline & $(0.195)$ & $(0.181)$ & $(0.181)$ & $(0.163)$ & $(0.158)$ \\
\hline \multirow[t]{2}{*}{ BIT*COL } & $-1.207^{* * *}$ & $-0.651^{*}$ & $-0.650^{* *}$ & 0.052 & 0.309 \\
\hline & $(0.269)$ & $(0.277)$ & $(0.276)$ & $(0.285)$ & $(0.287)$ \\
\hline \multirow[t]{2}{*}{ _cons } & -38.938 & -37.56 & -37.564 & -35.099 & -33.98 \\
\hline & $(34.274)$ & $(32.51)$ & $(32.513)$ & $(30.311)$ & (29.73) \\
\hline Time effects & Yes & Yes & Yes & Yes & Yes \\
\hline$N$ & 1215 & 1215 & 1215 & 1215 & 1215 \\
\hline
\end{tabular}

Note: Robust standard errors in parentheses; ${ }^{* *} p<0.01$, ** $p<0.05, * p<0.1$

(Source) Own calculation. 
between $15 \%$ and $20 \%$ shares of real FDI stock in phantom partners. Given the reported data, it seems realistic that Table 2 results are more probable than the results of Table 1. This confirms our hypothesis that outside of the phantom partners and the Western offshoot colonies, developing and least-developed partners that have both signed treaties with the UK and colonial ties tend to experience a decrease in FDI stocks as they primarily attract a horizontal FDI, which is connected to their market entry barriers and entering a BIT has a negative effect, thus undermining the host's policy of FDI-driven industrialization as hosts are unable to counterbalance the effect by attracting vertical-type FDI.

\section{Conclusion}

In this paper, we used the KK model to study the economic impact of BITs using British OFDI stock data. In general, we find that the horizontal motive is the primary reason for FDI for UK-based MNEs. Such result differs from existing studies, which typically find the importance of the vertical motive (Sirr et al., 2017; Maza et al., 2020). Our baseline analysis demonstrates that BITs act as a market access tool, resulting in a decrease of the horizontal type of inward FDI in a host economy. Furthermore, once phantom partners and Western offshoot colonies are accounted for, this result is extended to developing and least-developed partners, which have a colonial history with the UK. The results remain robust when we use various stock levels for phantom partners.

Our results raise concerning doubts regarding the effectiveness of development policies that attempt at facilitating inward FDI through the BIT mechanism. Our analysis dictates that host economies are unable to fully offset the negative effect of BIT entry. Henceforth, we argue that developing and least-developed economies should pursue vertical-FDI-driven policies to compensate, though, we are doubtful that outside of resource-rich economies, adopting such policies will be permissible.

These results challenge existing studies, which find that BITs are positively associated with FDI (Egger \& Pfaffermayr, 2004; Salacuse \& Sullivan, 2005; Kerner, 2009). We recommend that future research avoids common pitfalls, such as the use of net flow FDI data, cumulative treatment of BITs, and the role of phantom FDI, when investigating the economic impact of BITs.

\section{References}

Antweiler, W. (2020). Pacific Exchange Rate Service. Retrieved November 2020 from https://fx.sauder.ubc. 
$\mathrm{ca} /$ data.html

Arnold, J. M., \& Javorcik, B. S. (2009). Gifted kids or pushy parents? Foreign direct investment and plant productivity in Indonesia. Journal of International Economics, 79(1), 42-53.

Balasubramanyam, V. N., Salisu, M., \& Sapsford, D. (1999). Foreign direct investment as an engine of growth. Journal of International Trade \& Economic Development, 8(1), 27-40.

Bergstrand, J. H., \& Egger, P. (2007). A knowledge and physical capital model of international trade flows, foreign direct investment and multinational enterprises. Journal of International Economics, 73(2), 278-308.

Bergstrand, J. H., \& Egger, P. (2013). Shouldn't physical capital also matter for multinational enterprise activity? Review of International Economics, 21(5), 945-965.

Bevan, A. A., \& Estrin, S. (2004). The determinants of foreign direct investment into European transition economies. Journal of comparative economics, 32(4), 775-787.

Blonigen, B. A., \& Piger, J. (2014). Determinants of foreign direct investment. Canadian Journal of Economics/Revue Canadienne d'Économique, 47(3), 775-812.

Borensztein, E., De Gregorio, J., \& Lee, J. W. (1998). How does foreign direct investment affect economic growth? Journal of international Economics, 45(1), 115-135.

Busse, M., Königer, J., \& Nunnenkamp, P. (2010). FDI promotion through bilateral investment treaties: more than a BIT? Review of World Economics, 146(1), 147-177.

Carr, D. L., Markusen, J. R., \& Maskus, K. (2004). Competition for multinational investment in developing countries: Human capital, infrastructure, and market size. In Challenges to globalization: analyzing the economics (pp. 383-410). University of Chicago Press.

Cieślik, A. (2013). Horizontally integrated MNE and plant heterogeneity. Bank i Kredyt, 44(6), 605-622.

Cieślik, A. (2016). Exports versus FDI in Smith-Motta framework. Equilibrium. Quarterly Journal of Economics and Economic Policy, 11(2), 189-218.

Cieślik, A. (2018). Leader-follower model of reciprocal FDI and international trade. Argumenta Oeconomica, 41(2), 91-112.

Cieślik, A., \& Ryan, M. (2012). Productivity differences and foreign market entry in an oligopolistic industry. Open Economies Review, 23(3), 531-557.

Davies, R. B., \& Markusen J. R. (2020). The structure of multinational firms' international activities. NBER Working Paper, no. 26827.

Damgaard, J., Elkjaer, T., \& Johannesen, N. (2019). What is real and what is not in the global FDI network? International Monetary Fund Working Paper No. 19/274.

De Mello Jr, L. R. (1997). Foreign direct investment in developing countries and growth: A selective survey. The Journal of Development Studies, 34(1), 1-34.

Drabek, Z., \& Payne, W. (2002). The impact of transparency on foreign direct investment. Journal of Economic Integration, 777-810.

Egger, P., \& Pfaffermayr, M. (2004). The impact of bilateral investment treaties on foreign direct investment. Journal of Comparative Economics, 32(4), 788-804.

Feenstra, Robert C., Robert Inklaar, \& Marcel P. Timmer (2015). The Next Generation of the Penn World Table. American Economic Review, 105(10), 3150-3182. 
Gallagher, K. P., \& Birch, M. B. (2006). Do Investment Agreements Attract Investment? Evidence from Latin America. The Journal of World Investment \& Trade, 7(6), 961-974.

Gao, T. (2003). Ethnic Chinese networks and international investment: Evidence from inward FDI in China. Journal of Asian Economics, 14(4), 611-629.

Guadalupe, M., Kuzmina, O., \& Thomas, C. (2012). Innovation and foreign ownership. American Economic Review, 102(7), 3594-3627.

Haftel, Y. Z. (2008). The effect of US BITs on FDI inflows to developing countries: signaling or credible commitment? Unpublished, U of Illinois.

Hallward-Driemeier, M. (2003). Do bilateral investment treaties attract foreign direct investment? Only a bit $\cdots$ and they could bite. The World Bank.

Helpman, E. (1984). A simple theory of trade with multinational corporations. Journal of Political Economy, 92(3), 451-471.

Helpman, E., \& Krugman, P. (1985). Market structure and foreign trade: Increasing returns, imperfect competition and the international economy. Cambridge: MIT Press.

Helpman, E., Melitz, M. J., \& Yeaple, S. R. (2004). Export versus FDI with heterogeneous firms. American Economic Review, 94(1), 300-316.

Heritage Foundation. (2020). Index of Economic Freedom. Retrieved December, 2020, from https://www.he ritage.org/index/explore

Horstmann, I., \& Markusen, J. R. (1987). Strategic investments and the development of multinationals. International Economic Review, 28(1), 109-121.

International Monetary Fund. (2019). Glossary of Foreign Direct Investment Terms. Retrieved December, 2020, from https://www.imf.org/external/np/sta/di/glossary.pdf

Jacobs, M. N. (2017). Do bilateral investment treaties attract foreign direct investment to developing countries? A review of the empirical literature. International Relations and Diplomacy, 5(10), 583-593.

Kerner, A. (2009). Why should I believe you? The costs and consequences of bilateral investment treaties. International Studies Quarterly, 53(1), 73-102.

Krugman, P. (1983). The new theories of international trade and the multinational enterprise. The multinational corporation in the 1980s, 57-73.

Lee, C. Y., \& Johnston, N. P. (2016). Improving reputation BIT by BIT: Bilateral investment treaties and foreign accountability. International Interactions, 42(3), 429-451.

Markusen, J. R. (1984). Multinationals, multi-plant economies and the gains from trade. Journal of International Economics, 16(3-4), 205-226.

Markusen, J. R. (2002). Multinational firms and the theory of international trade. Cambridge, Mass.: MIT Press.

Markusen, J., \& Venables, A. (1998). Multinational firms and the new trade theory. Journal of International Economics, 46(2), 183-203.

Markusen, J., \& Venables, A. (2000). The theory of endowment, intra-industry and multi-national trade. Journal of International Economics, 52(2), 209-234.

Maza, A., Gutiérrez-Portilla, P., \& Villaverde, J. (2020). On the drivers of UK direct investment in the Spanish regions: A spatial Durbin approach. Growth and Change, 51(2), 646-675. 
Neumayer, E., \& Spess, L. (2005). Do bilateral investment treaties increase foreign direct investment to developing countries? World development, 33(10), 1567-1585.

Office for National Statistics. (2020). Foreign direct investment involving UK companies. Retrieved December, 2020, from https://www.ons.gov.uk/economy/nationalaccounts/balanceofpayments/bulletins/foreigndir ectinvestmentinvolvingukcompanies/latest

Rose-Ackerman, S., \& Tobin, J. (2005). Foreign direct investment and the business environment in developing countries: The impact of bilateral investment treaties. Yale Law \& Economics Research Paper, (293). doi: 10.2139/ssrn.557121

Salacuse, J. W., \& Sullivan, N. P. (2005). Do BITs really work: An evaluation of bilateral investment treaties and their grand bargain. Harv. Int'l LJ, 46, 67. doi: 10.1093/acprof:oso/9780195388534.003.0005

Silva, J. S., \& Tenreyro, S. (2006). The log of gravity. The Review of Economics and Statistics, 88(4), 641-658.

Silva, J. S., \& Tenreyro, S. (2011). Further simulation evidence on the performance of the Poisson pseudo-maximum likelihood estimator. Economics Letters, 112(2), 220-222.

Sinha, U. B. (2010). Strategic licensing, export, FDI, and host country welfare. Oxford Economic Paper, 62(1), 114-131.

Sirr, G., Garvey, J., \& Gallagher, L. A. (2017). Bilateral investment treaties and foreign direct investment: Evidence of asymmetric effects on vertical and horizontal investments. Development Policy Review, 35(1), 93-113.

Sauvant, K. P., \& Sachs, L. E. (2009). The effect of treaties on foreign direct investment: Bilateral investment treaties, double taxation treaties, and investment flows. Oxford University Press.

UNCTAD Investment Policy Hub. (2020). United Kingdom's bilateral investment treaties. Retrieved December, 2020, from https://investmentpolicy.unctad.org/international-investment-agreements/countr ies/221/united-kingdom

UNCTAD. (1998). The impact of foreign direct investment of BITs. In Bilateral Investment Treaties in the Mid-1990s. New York, N.Y.: United Nations.

UNCTAD. (2020a). World Investment Report 2019: International production beyond the pandemic. Retrieved December, 2020, from https://unctad.org/en/PublicationsLibrary/wir2018_en.pdf

UNCTAD. (2020b). International Investment Policy Hub. Retrieved from November, 2020, from https://inv estmentpolicy.unctad.org/international-investment-agreements

Waldkirch, A. (2010). The structure of multinational activity: evidence from Germany. Applied Economics, 42(24), 3119-3133.

World Bank ICSID. (2020). Database of bilateral investment treaties. Retrieved November, 2020, from https://icsid.worldbank.org/resources/databases/bilateral-investment-treaties

World Trade Organization. (2019). World Trade Statistical Review. Retrieved November, 2020, from https://www.wto.org/english/res_e/statis_e/wts2019_e/wts19_toc_e.htm

World Trade Organization. (2021). Preferential Trade Agreements database. Retrieved March 2021 from http://ptadb.wto.org/ptaList.aspx 


\section{Appendix}

Figure A1. Outward FDI of UK-based MNEs in US\$ billion to the world, average 2009-2017

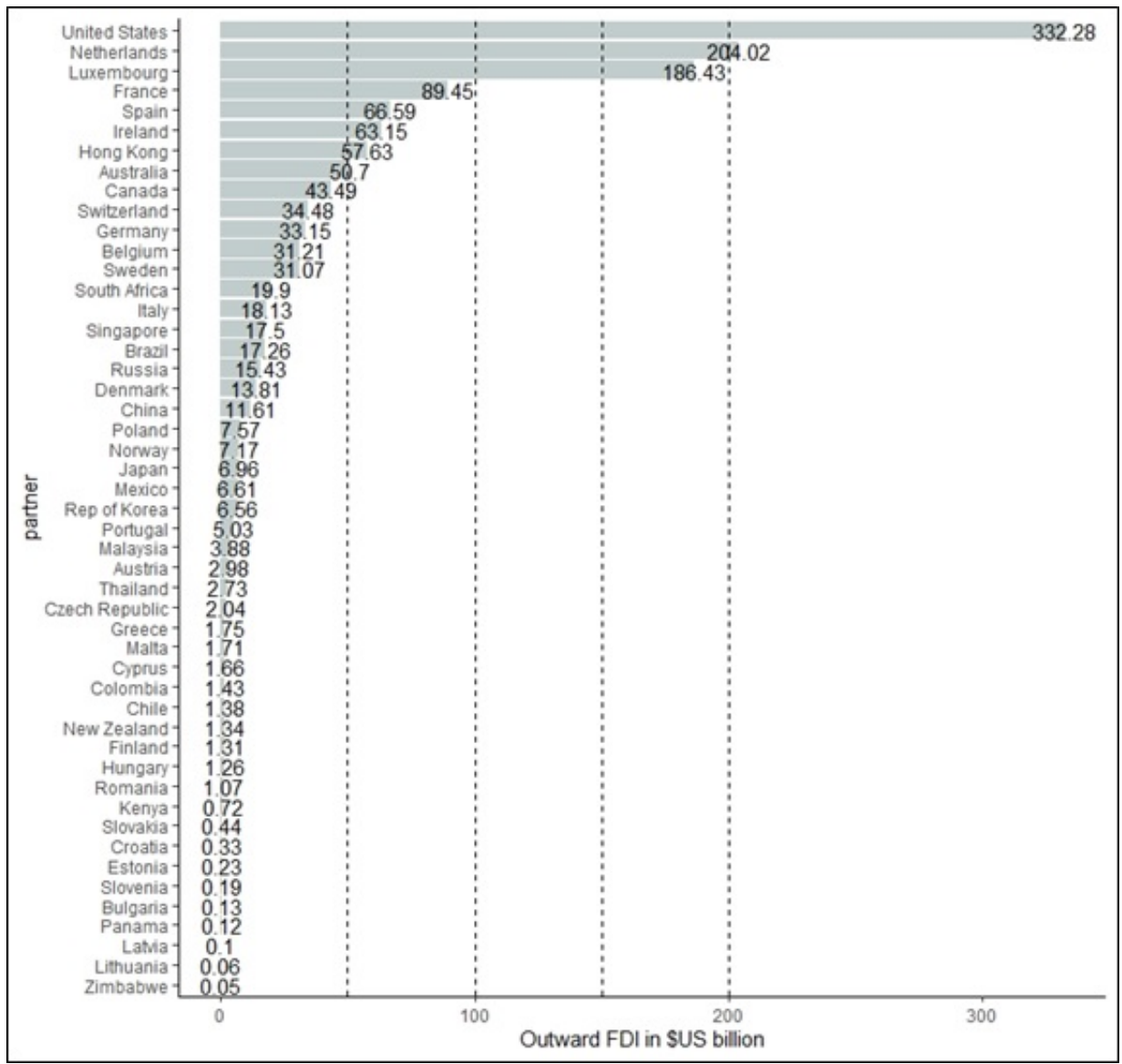

(Source) Own summary. 


\title{
Part A
}

Table A1. Sample of Countries Used in the Empirical Analysis

\begin{abstract}
Pooled partner sample Albania, Algeria, Angola, Argentina, Armenia, Australia, Austria, Bahrain, Bangladesh, Barbados, Belgium, Belize, Benin, Bolivia, Botswana, Brazil, Brunei Darussalam, Bulgaria, Burkina Faso, Burundi, Cambodia, Cameroon, Canada, Central African Republic, Chile, China, Colombia, Costa-Rica, Croatia, Cyprus, Czech Republic, Denmark, Dominican Republic, D.R. of the Congo, Ecuador, El Salvador, Estonia, Ethiopia, Finland, Fiji, France, Gabon, Gambia, Germany, Ghana, Greece, Guatemala, Haiti, Honduras, Hungary, Hong Kong, Iceland, India, Indonesia, Italy, Iran, Ireland, Israel, Japan, Jamaica, Jordan, Kazakhstan, Kenya, Korea (Rep of), Kyrgyzstan, Kuwait, Latvia, Lesotho, Liberia, Lithuania, Luxembourg, Macau, Madagascar, Malaysia, Mali, Malawi, Maldives, Malta, Mauritius, Mauritania, Mexico, Moldova, Mongolia, Morocco, Mozambique, Myanmar, Namibia, Nepal, Netherlands, New Zealand, Nicaragua, Niger, Nigeria, Norway, Pakistan, Panama, Paraguay, Peru, Philippines, Poland, Portugal, Qatar, Romania, Russia, Rwanda, Saudi Arabia, Senegal, Serbia, Sierra Leone, Singapore, Slovakia, Slovenia, South Africa, Spain, Sri Lanka, Syria, Sudan, Swaziland, Sweden, Switzerland, Tanzania, Taiwan, Tajikistan, Thailand, Togo, Trinidad and Tobago, Tunisia, Turkey, Venezuela, Vietnam, Yemen, Ukraine, Uruguay, Uganda, United Arab Emirates, United Kingdom, United States, Zambia, Zimbabwe
\end{abstract}

BIT sample

Colony sample

Offshore sample

Western offshoot colonies sample

GSP sample
Albania, Argentina, Armenia, Bahrain, Bangladesh, Barbados, Belize, Benin, Bulgaria, Burundi, Chile, China, Cameroon, Colombia, Costa Rica, Croatia, Czech Republic, Egypt, El Salvador, Estonia, Ghana, Haiti, Honduras, Hungary, Hong Kong, Indonesia, Jamaica, Jordan, Kazakhstan, Kenya, Korea (Rep of), Latvia, Lithuania, Malaysia, Malta, Mauritius, Mexico, Moldova, Mongolia, Morocco, Mozambique, Nepal, Nigeria, Pakistan, Panama, Paraguay, Peru, Philippines, Poland, Romania, Russia, Senegal, Serbia, Sierra Leone, Singapore, Slovakia, Slovenia, South Africa, Sri Lanka, Swaziland, Tanzania, Thailand, Trinidad and Tobago, Tunisia, Turkey, Venezuela, Viet Nam, Ukraine, Uruguay, Uganda, United Arab Emirates

Australia, Bahrain, Bangladesh, Belize, Botswana, Brunei Darussalam, Canada, Cyprus, Egypt, Fiji, Gambia, Ghana, Hong Kong, India, Ireland, Israel, Jamaica, Jordan, Kenya, Kuwait, Lesotho, Malaysia, Malawi, Maldives, Malta, Mauritius, Myanmar, New Zealand, Nigeria, Pakistan, Qatar, Sierra Leone, Singapore, South Africa, Sri Lanka, Sudan, Swaziland, Tanzania, Trinidad and Tobago, Yemen, Uganda, United Arab Emirates, United States, Zambia, Zimbabwe

Belize, Cyprus, Hong Kong, Luxembourg, Macau, Malaysia, Mauritius, Netherlands, Panama, Singapore

Australia, Canada, New Zealand, South Africa, United States

Algeria, Angola, Armenia, Bangladesh, Benin, Bolivia, Burkina Faso, Burundi, Cambodia, Central African Republic, D.R. of the Congo, Ethiopia, Gambia, Ghana, Haiti, India, Indonesia, Jordan, Kenya, Kyrgyzstan, Lesotho, Liberia, Madagascar, Malawi, Mali, Mauritania, Mongolia, Mozambique, Myanmar, Nepal, Niger, Nigeria, Pakistan, Philippines, Rwanda, Senegal, Sierra Leone, Sri Lanka, Tanzania, Togo, Viet Nam, Yemen, Zambia 
Table A2. Description of Variables

\begin{tabular}{|c|c|c|}
\hline Variable & Description & Data source \\
\hline FDI & $\begin{array}{l}\text { Bilateral direct investment equity stock data from non-resident entities, } \\
\text { includes investment by a direct investor in its direct investment enterprise } \\
\text { (immediate or not), retail funds, real estate investment (including investment } \\
\text { properties and vacation homes), pass-through transactions, transactions that } \\
\text { reach or surpass the threshold of } 10 \% \text { or more voting power, reverse } \\
\text { investment by a direct investment enterprise in its own immediate or indirect } \\
\text { investor (IMF, 2019). The data is reported in £GBP and converted using } \\
\text { PACIFIC exchange rate (Antweiler, 2020) to \$US. }\end{array}$ & $\begin{array}{l}\text { Office for National } \\
\text { Statistics } \\
(2020)\end{array}$ \\
\hline GDP_SUM & $\begin{array}{l}\text { Log of GDP sum (in constant } 2011 \text { \$US million, expressed at chained PPPs), } \\
\text { computed as: } \\
\ln \left[\left(Y_{i t}+Y_{j t}\right)\right]\end{array}$ & Penn World Table \\
\hline GDP_DIFF & $\begin{array}{l}\text { Log of GDP difference (in constant } 2011 \text { \$US million, expressed at chained } \\
\text { PPPs), computed as: } \\
\ln \left[\left(Y_{i t}-Y_{j t}\right)^{2}\right]\end{array}$ & Penn World Table \\
\hline HC_DIFF & $\begin{array}{l}\text { Log of human capital difference, adjusted for the number of employed } \\
\text { population, computed as: } \\
\ln \left[\left|\frac{H_{i t}}{L_{i t}}-\frac{H_{j t}}{L_{j t}}\right|\right]\end{array}$ & Penn World Table \\
\hline DISTANCE & $\begin{array}{l}\text { Log of geographical distance between source and host country (between } \\
\text { capital cities, in } \mathrm{km} \text { ) }\end{array}$ & CEPII \\
\hline $\mathrm{TF}_{\text {PARENT }} / \mathrm{TC}_{\text {HOST }}$ & Trade freedom index of home or host country, ranges from 0 to 100 & Heritage Foundation \\
\hline $\mathrm{IC}_{\mathrm{HOST}}$ & Investment freedom index of home or host country, ranges from 0 to 100 & Heritage Foundation \\
\hline BIT & $\begin{array}{l}\text { Dummy variable, reflects if host has an active bilateral investment treaty } \\
\text { with the United Kingdom }\end{array}$ & $\begin{array}{l}\text { UNCTAD } \\
\text { World Bank ICSID }\end{array}$ \\
\hline COLONY & $\begin{array}{l}\text { Dummy variable, reflects if host was in a colonial relationship with the United } \\
\text { Kingdom }\end{array}$ & CEPII \\
\hline $\mathrm{BIT} * \mathrm{COL}$ & Interaction term for BIT and COLONY & Own calculation \\
\hline
\end{tabular}

(Source) Own summary. 
Table A3. Summary Statistics

\begin{tabular}{lccccc}
\hline \multicolumn{1}{c}{ Variable } & Obs & Mean & Std. Dev. & Min & Max \\
\hline FDI & 1260 & 10.029 & 38.695 & 0 & 418.209 \\
GDP_DIFF & 1260 & 28.925 & 1.266 & 14.216 & 33.15 \\
HC_DIFF & 1260 & -1.069 & 1.99 & -8.632 & 3.289 \\
GDP_SUM & 1260 & 14.841 & 0.33 & 14.588 & 16.884 \\
DISTANCE & 1260 & 8.409 & 0.869 & 5.78 & 9.86 \\
TC & 1260 & 76.478 & 10.905 & 37.1 & 95 \\
IC & 1260 & 56.52 & 22.71 & 0 & 95 \\
TFOST & 1260 & 84.644 & 2.181 & 82.4 & 87.6 \\
BIT & 1260 & 0.476 & 0.5 & 0 & 1 \\
COLONEN & 1260 & 0.328 & 0.469 & 0 & 1 \\
BIT*COL & 1260 & 0.162 & 0.369 & 0 & 1 \\
\hline
\end{tabular}

Table A4. Pairwise Correlations

\begin{tabular}{|c|c|c|c|c|c|c|c|c|c|c|c|}
\hline Variables & (1) & (2) & (3) & (4) & (5) & (6) & (7) & (8) & (9) & (10) & (11) \\
\hline (1) FDI & 1.000 & & & & & & & & & & \\
\hline (2) GDP_DIFF & 0.059 & 1.000 & & & & & & & & & \\
\hline (3) $\mathrm{HC}$ _DIFF & -0.047 & 0.318 & 1.000 & & & & & & & & \\
\hline (4) GDP_SUM & 0.446 & -0.059 & -0.336 & 1.000 & & & & & & & \\
\hline (5) DISTANCE & -0.310 & 0.152 & -0.060 & -0.032 & 1.000 & & & & & & \\
\hline (6) $\mathrm{TC}_{\mathrm{HOST}}$ & 0.230 & -0.083 & 0.180 & 0.073 & -0.320 & 1.000 & & & & & \\
\hline (7) $\mathrm{IC}_{\mathrm{HOST}}$ & 0.267 & -0.002 & 0.284 & 0.049 & -0.337 & 0.697 & 1.000 & & & & \\
\hline (8) TF PFARENT $_{\text {Par }}$ & 0.007 & -0.074 & 0.010 & -0.130 & -0.000 & -0.027 & -0.104 & 1.000 & & & \\
\hline (9) $\mathrm{BIT}$ & -0.190 & 0.056 & -0.014 & -0.017 & 0.144 & 0.059 & 0.059 & 0.004 & 1.000 & & \\
\hline (10) COLONY & 0.052 & 0.131 & 0.171 & -0.027 & 0.300 & -0.103 & 0.006 & 0.000 & 0.054 & 1.000 & \\
\hline (11) $\mathrm{BIT}^{*} \mathrm{COL}$ & -0.066 & 0.095 & 0.084 & -0.055 & 0.212 & -0.103 & 0.010 & 0.005 & 0.461 & 0.628 & 1.000 \\
\hline
\end{tabular}

(Source) Own summary.

\section{Part B}

In this part, we investigate a case, whether inclusion of other conditions of market entry possibly can indicate a downward bias in our originally reported results. To do this, we employ data on the Generalized System of Preferences (GSP) of WTO. Alike to the BIT mechanism, the GSP system was established to promote freer trade between the developed and developing countries. For this, we use data from the Database on Preferential Trade Agreements (WTO, 2021) to construct a dummy, which takes value of 1 if a particular host is a beneficiary under the GSP, and 0 otherwise $\left(G S P_{i j t}\right)$. Because the BIT mechanism, and the GSP system both target barriers to national market entry, we should observe very similar pattern in terms of the obtained signs between the two dummies. The estimating equation (1) now takes the form: 


$$
\begin{aligned}
F D I_{i j t}= & \beta_{0}+\beta_{1} \ln \left[\left(Y_{i t}-Y_{j t}\right)^{2}\right]+\beta_{2} \ln \left[\left|\frac{H_{i t}}{L_{i t}}-\frac{H_{j t}}{L_{j t}}\right|\right]+\beta_{3} \ln \left[\left(Y_{i t}+Y_{j t}\right)\right] \\
& +\beta_{4} \ln \left[D I S T A N C E_{i j}\right]+\beta_{5} T F_{i t}+\beta_{6} T C_{j t}+\beta_{7} I C_{j t}+\beta_{8} B I T_{i j t} \\
& +\beta_{9} C O L O N Y_{i j}+\beta_{10}\left[B I T_{i j t}{ }^{*} C O L O N Y_{i j}\right]+\beta_{11} G S P_{i j t}+\epsilon_{i j t}
\end{aligned}
$$

where: $F D I_{i j t}$ is bilateral outward FDI stock from source country $i$ to host country $j$ in year $t_{i t}$, and $Y_{i t}, Y_{j t}$ are GDPs of country $i$ and country $j$ in year $t, \frac{H_{i t}}{L_{i t}}, \frac{H_{j t}}{L_{j t}}$ are human capital per worker endowments for country $i$ and country $j$ in year $t, D I S T A N C E_{i j}$ is the geographical distance between the capitals of country $i$ and country $j, B I T_{i j t}$ is dummy variable, reflecting country $i$ and country $j$ membership in the bilateral investment treaty in year $t, C O L O N Y_{i j}$ is dummy variable, reflecting the colonial relationship between country $i$ and country $j$, while $T F_{i t}, T C_{j t}$ and $I C_{j t}$ are trade and investment freedom indexes for country $j$ and country $i$ in year $t,\left[B I T_{i j t}{ }^{*} C O L O N Y_{i j}\right]$ is an interaction term for two dummies, which approximates the effect of country $i$ membership in the bilateral investment treaty in year $t$ and having the colonial relationship with country $j, G S P_{i j t}$ is dummy variable, indicating country $i$ and country $j$ participation in a preferential trade agreement under the GSP system in year $t, \epsilon_{i j t}$ is the error term, for $i=$ United Kingdom, $j=1, \cdots, 140$ investment partners, $t=2008, \cdots, 2017$, and $\beta$ 's are the parameters to be estimated.

We consider two estimation cases: general case with all partners present, and a restricted case with the exclusion of phantom FDI partners and Western offshoots, Table 1B presents the results. Column (1) reports general case estimation results without one period lagged independent variables, having controlled for time effects. The results are quantitatively similar to the originally reported results in Table 1, furthermore, the parameter sign on the GSP proxy is negative and significant at the $1 \%$ level. Column (2) describes results, obtained from a restricted partner sample, having controlled for time effects. Again, the results are akin to the originally reported results in Table 2 , with the parameters on the GSP proxy and BIT*COL interaction term being negative and significant at the $1 \%$ level. Column (3) presents general case estimation results with one period lagged independent variables, having controlled for time effects. The obtained parameters on the GSP proxy and BIT dummy remain negative and significant at the $1 \%$ level. Finally, column (4) reports results from the restricted case, having controlled for time effects. The estimated parameters on the GSP proxy and BIT*COL interaction term remain negative and significant at the $1 \%$ level.

In sum, the inclusion of additional market entry proxy does not cause our results to change. The originally obtained parameters and their signs remain robust throughout the estimation. 
Table 1B. Estimation Results with the GSP Dummy

\begin{tabular}{|c|c|c|c|c|}
\hline Exp. var. & (1) & (2) & (3) & (4) \\
\hline \multirow[t]{2}{*}{ GDP_DIFF } & -0.0941 & $-0.118^{* *}$ & $-0.0992^{*}$ & -0.0397 \\
\hline & $(0.0544)$ & $(0.0388)$ & $(0.0497)$ & $(0.0367)$ \\
\hline \multirow[t]{2}{*}{ HC_DIFF } & 0.121 & 0.0515 & 0.102 & 0.0641 \\
\hline & $(0.0895)$ & $(0.0672)$ & $(0.0893)$ & $(0.0682)$ \\
\hline \multirow[t]{2}{*}{ GDP_SUM } & $2.021^{* * *}$ & $1.793^{* * *}$ & $1.946^{* * *}$ & $1.976^{* * *}$ \\
\hline & $(0.221)$ & $(0.218)$ & $(0.217)$ & $(0.166)$ \\
\hline \multirow[t]{2}{*}{ DISTANCE } & $-0.576^{* * *}$ & $-0.774^{* * *}$ & $-0.556^{* * *}$ & $-0.725^{* * *}$ \\
\hline & $(0.0766)$ & $(0.0724)$ & $(0.0725)$ & $(0.0725)$ \\
\hline \multirow[t]{2}{*}{$\mathrm{TC}_{\text {HOST }}$} & $0.0252^{*}$ & 0.00284 & $0.0280^{*}$ & $0.0308^{* * *}$ \\
\hline & $(0.0111)$ & $(0.0103)$ & $(0.0113)$ & $(0.00877)$ \\
\hline \multirow[t]{2}{*}{$\mathrm{IC}_{\text {HOST }}$} & $0.0420^{* * *}$ & $0.0198^{* * *}$ & $0.0421^{* * *}$ & $0.00833^{*}$ \\
\hline & $(0.00695)$ & $(0.00587)$ & $(0.00659)$ & $(0.00395)$ \\
\hline \multirow[t]{2}{*}{ TF $_{\text {PARENT }}$} & 0.0746 & 0.149 & 0.0574 & 0.173 \\
\hline & $(0.0539)$ & $(0.408)$ & $(0.0530)$ & $(0.483)$ \\
\hline \multirow[t]{2}{*}{ BIT } & $-1.792^{* * *}$ & $-1.068^{* * *}$ & $-1.468^{* * *}$ & $-1.174^{* * *}$ \\
\hline & $(0.174)$ & $(0.145)$ & $(0.174)$ & $(0.148)$ \\
\hline \multirow[t]{2}{*}{ COLONY } & $0.506^{* * *}$ & $0.488^{* *}$ & $0.594^{* * *}$ & $1.013^{* * *}$ \\
\hline & $(0.148)$ & $(0.173)$ & $(0.161)$ & $(0.140)$ \\
\hline \multirow[t]{2}{*}{ BIT*COL } & $1.622^{* * *}$ & $-1.364^{* * *}$ & $1.130^{* * *}$ & $-1.524^{* * *}$ \\
\hline & $(0.298)$ & $(0.327)$ & $(0.309)$ & $(0.318)$ \\
\hline \multirow[t]{2}{*}{ GSP } & $-4.318^{* * *}$ & $-3.919^{* * *}$ & $-4.598^{* * *}$ & $-4.116^{* * *}$ \\
\hline & $(0.416)$ & $(0.362)$ & $(0.427)$ & $(0.364)$ \\
\hline \multirow[t]{2}{*}{ _cons } & $-31.89^{* * *}$ & -29.60 & $-29.59^{* * *}$ & -38.54 \\
\hline & $(5.305)$ & (34.03) & (5.309) & (40.08) \\
\hline Time effects & Yes & Yes & Yes & Yes \\
\hline$N$ & 1260 & 1125 & 1260 & 1125 \\
\hline
\end{tabular}

Note: Robust standard errors in parentheses ${ }^{*} p<0.05,{ }^{* *} p<0.01,{ }^{* * *} p<0.001$

(Source) Own calculation. 